\title{
16 Aspects of Demography in Post-Fire Mediterranean Plant Communities of Greece
}

\author{
M. Arianoutsou
}

\subsection{Introduction}

Fire is a major ecological factor in many biomes of the world (Rundel 1981). In the Mediterranean ecosystems fire acts as an integral part of their evolutionary history, having shaped their adaptive traits (Naveh 1975). It is beyond any doubt that the specific characteristics of fire regimes have a profound effect on these ecosystems (Mooney and Conrad 1977), the most important of which is related to community and population structure. These are critical issues for any conservation attempt. In this perspective, the biological features that are mostly influenced by fire are reproductive and demographic characteristics which assure a rapid reestablishment by resprouting and/or seed germination (Keeley and Zedler 1978; Arianoutsou and Margaris 1981a). The specific regeneration behaviour of the plants is closely related to their physiological traits and is strongly influenced by fire regime (fire season, intensity, interval).

Resprouting occurs from dormant buds or lignotubers effectively protected by the soil. It starts almost immediately after fire in the evergreen sclerophyllous species, while it takes several months, until the onset of the rainy season for the seasonal dimorphic (phryganic) species. This difference has been attributed to the different depths of their root systems. The resprouting ability of the plants is determined by their developmental phase. Many shrubby taxa are successful resprouters, either obligate or facultative.

In several Mediterranean ecosystems, fire has been shown to trigger a flush of germination (Purdie 1977; Trabaud 1980; Arianoutsou and Margaris 1981b). Post-fire seed germination is an adaptation of the species which form permanent soil seed banks of hard-coated seeds (Cistaceae, Leguminosae) and of those with a canopy seed bank (Proteaceae, Pinaceae). Seed germination has been attributed to several factors such as mechanical rupture of the hard seed coat induced by the increased temperatures developing during fire (Arianoutsou and Margaris $1981 \mathrm{~b}$; review 
in Rundel 1981), inactivation of germination inhibitors present in the soil (Christensen and Muller 1975; Keeley and Keeley 1989), effect of charred woody stems (Keeley and Nitzberg 1984) and change in light quality (Roy and Arianoutsou 1985).

The temporal destruction of either the whole or the aboveground part of the mature plant by a fire incident triggers the restart of the demographic cycle of the community through the relevant cycle of the plant taxa present. Many studies have been done in California, Australia, and South Africa on plant community diversity and dynamics in relation to fire, and these are extensively reviewed by Kruger (1983). Not as much work, though, has been done in the Mediterranean Basin, apart from a few demographic studies (Naveh 1974; Papanastasis 1977; Arianoutsou and Margaris 1981a; Arianoutsou 1984; Trabaud and Oustric 1989; Ne'eman et al 1993). This chapter aims to review and synthesize information on the dynamics of post-fire Mediterranean communities in Greece, as part of a broader study which is evolving under the framework of two research projects sponsored by the European Union - Modelling vegetation dynamics and degradation in Mediterranean ecosystems (MODMED) and Management techniques for optimisation of suppression and minimisation of wildfire effects (PROMETHEUS).

\subsection{Mediterranean Ecosystems of Greece}

Mediterranean ecosystems constitute $40 \%$ of the terrestrial vegetation of Greece. They can be grouped into three major types according to the prevailing vegetation, and they cover a rainfall regime of very low precipitation (close to $100 \mathrm{~mm}$ ) to adequately higher $(700-900 \mathrm{~mm})$. Analytically, the three types are:

1. Communities with seasonal dimorphic dwarf plants, known as phrygana. This community is found mainly in the complex of Cyclades islands, in the islands of Crete, Limnos, Chios, Kefalonia, Lefkada, in West Akarnania and in Southeast Peloponnese. Their vertical structure is restricted to one single layer, that of the dominant shrubs, which are seldom taller than $50 \mathrm{~cm}$. At the mature stage, phrygana is a relatively closed community, leaving some open space between the individuals. Among the most common woody plants are Coridothymus capitatus (thyme), Phlomis fruticosa (Jerusalem sage), Cistus spp. (rockroses), Sarcopoterium spinosum (thorny burnet) and Euphorbia acanthothamnos (Greek spiny spurge). The majority of the woody species are 
seasonal dimorphic, that is they change their leaves and type of branches twice a year, in order to face water stress. Euphorbia acanthothamnos is a summer drought plant. They are all shallow rooted and they grow on calcareous, relatively poor soils.

2. Communities with evergreen sclerophyllous shrubby plants, otherwise referred to as maquis. These cover part of the Halkidiki peninsula in Macedonia, part of continental central Greece and parts of the islands in the Ionian Sea. Deep-rooted plants taller than $1 \mathrm{~m}$, such as Quercus coccifera (kermes oak), are the predominant species in these communities. Other common taxa are Pistacia lentiscus (lentisc), Arbutus unedo (strawberry tree), Myrtus communts (myrtle), Juniperus phoenicea (phoenician juniper) and Juniperus oxycedrus (prickly juniper). Their leaves are thick, larger than those of the phryganic species and remain the same throughout the year, having a life span of two years. They form very dense stands of one layer, leaving almost no space between individuals at the mature stage. They grow on more fertile soils.

3. Forest communities with pine trees. Pinus halepensis (Aleppo pine) forests are found in Attica, in Euboia, in western Peloponnese and in Halkidiki, while Pinus brutia (brutia pine) forests grow on the islands of the north and southeast Aegean, in Crete and its islets, (see Fig. 16.1a). The trees can be up to $15 \mathrm{~m}$ tall, and generally have a rather poor understory stratum at the middle of their life span (which can be as long as 100 years). However, species diversity is quite high immediately after fire and rich also at the mature stage. The understorey stratum consists of either phryganic species or species of the evergreen sclerophyllous formations.

Phrygana exploit the areas with low precipitation and higher summer temperatures, while evergreen sclerophyllous ecosystems occur in more humid and less warm environmental regimes. Mediterranean coniferous forest can be found in situations closer to those prevailing in the latter case (Fig. 16.1b).

\subsection{Fire Frequency}

Fire incidents in the Mediterranean Basin are very common and a high frequency of fires has extended back into the past. Evidence of fire can be identified in the Iron Age, 2600 years B.P., when shepherds and farmers set fires in order to open the forest and the ground for improving pasture and cultivated land (Barry 1960; Dugrand 1964). 


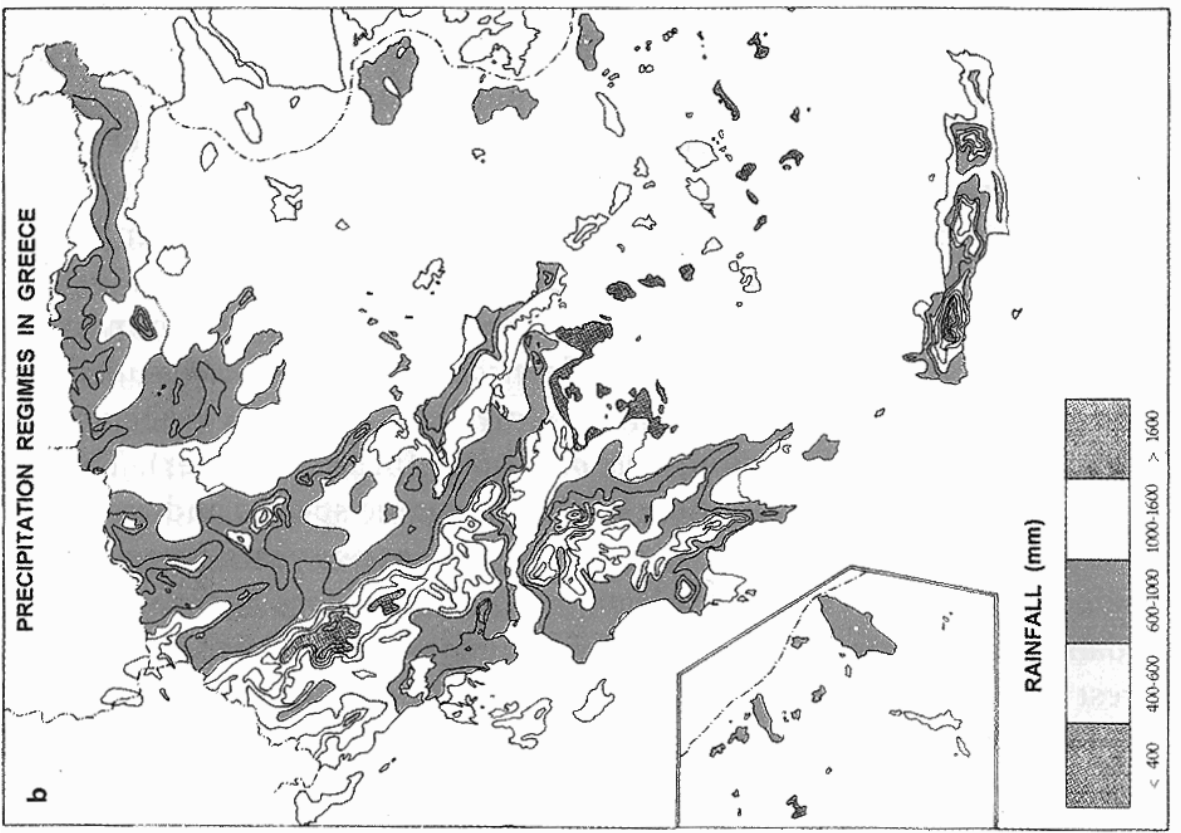

列

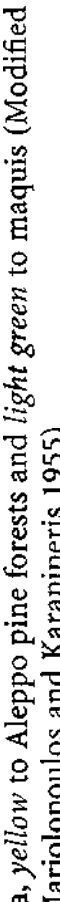

$\stackrel{\pi}{ \pm}$

응

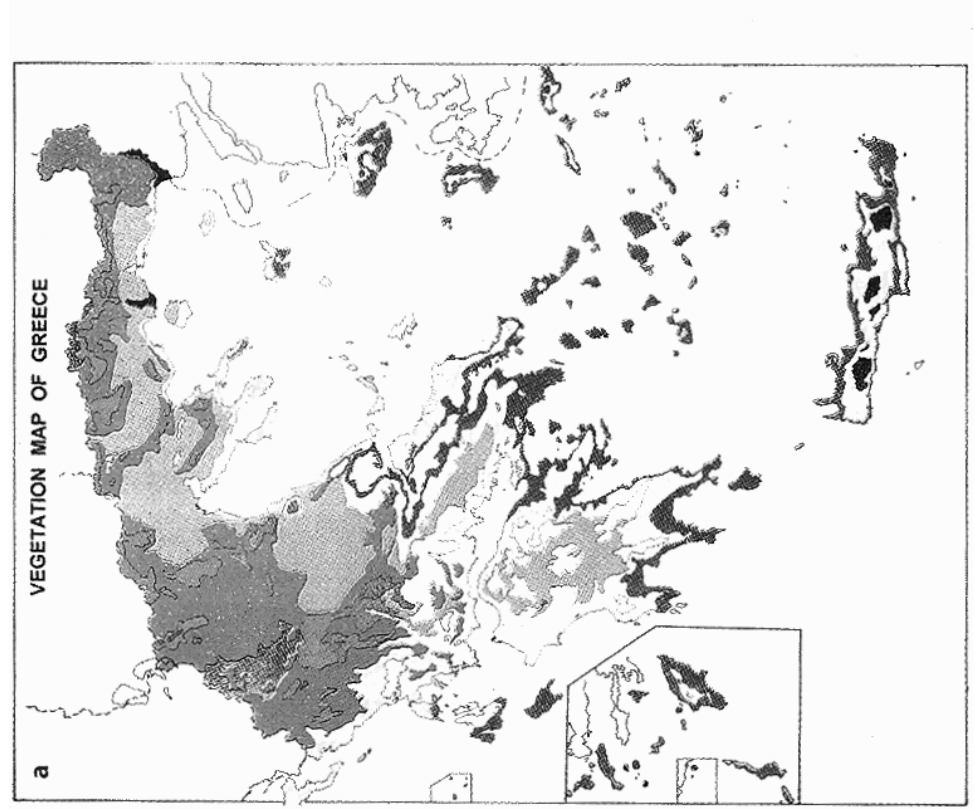

它它

율 동 
In Greece, the first archaeological evidence of fire occurrence in the xerophytic landscapes goes back to the end of the Middle Stone Age: remnants of ashed wood in the Kastritsa cave, near Ioannina Lake (Higgs et al. 1967). Liakos (1973) has reviewed the early use of fire and wildfire in ancient Greece.

Most fire events occur in evergreen sclerophyllous ecosystems (Fig. 16.2), where they consume approximately 13024 ha year $^{-1}$ (Table 16.1), which corresponds to nearly $50 \%$ of the total area burned. Following in size are fire events occurring in phrygana and $P$. halepensis forests (Table 16.1; Fig. 16.2 and 16.3). Most of the fires are caused accidentally or by arson.

While there are extensive and detailed studies on fire frequency in California, South Africa and Australia, there are but a few data for the Mediterranean Basin. Le Houerou (1973) states that the so-called red belt of southern France is burned regularly every $25-30$ years. Forest Service records in Greece are scarce and sometimes not very reliable. Moreover, these data do not reveal any clear pattern of fire frequency, presumably due to multiple reasons encountered as possible fire causes.

\subsection{Plant Adaptive Traits}

Table 16.2 summarizes the adaptive traits that taxa dominant in the Mediterranean ecosystems of Greece have evolved in order to cope with fire. Most of the phanerophytes are resprouters and generally obligate

Table 16.1. Vegetation types and five data. (Period of reference 1965-1990; data adapted from Kailidis 1992)

Vegetation type

Total area

burned (ha)
Total number of fires
Mean area burned/year (ha)
Abies spp. forest

Mixed coniferous forests

Pinus nigra forests

Pinus halepensis forests

Pinus brutia forests

Other coniferous forests

Forests with deciduous Quercus spp.

Forests with other deciduous species

Evergreen sclerophyllous shrublands

Phrygana
1304

2534

9152

122015

61684

1288

42459

13393

338608

167084
147

11

383

4385

1159

139

1514

553

10801

4020
50.15

97.46

352.00

4692.88

2372.46

49.54

1633.04

515.12

13023.38

6426.31 
$1965-1990$

TOTAL NUMBER OF FFRES

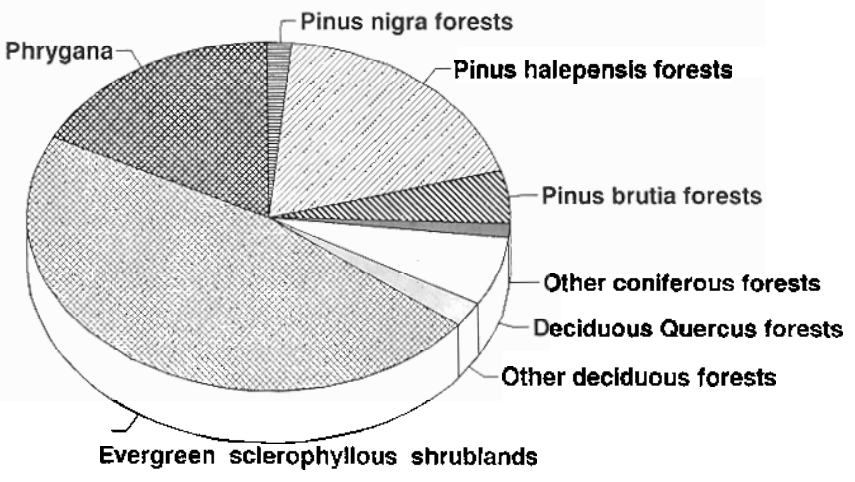

Fig. 16.2. Percentage of fire incidents occurring in several vegetation types in Greece between 1965-1990. (Data adapted from Kailidis 1992)

\section{$1965-1990$ \\ AREA BURNED / VEGETATION TYPE}

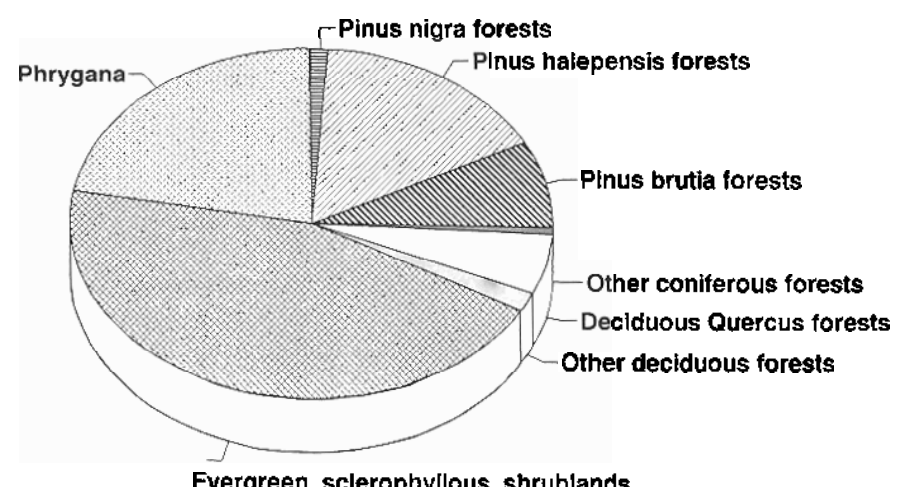

Evergreen sclerophyllous shrublands

Fig. 16.3. Percentage of areas burned in several vegetation types in Greece between 19651990. (Data adapted from Kailidis 1992)

resprouters. The only exceptions are Pinus halepensis and Pinus brutia which are obligate seeding species. Among the chamaephyte subshrubs both regenerative modes are encountered, so as the taxa can be characterised as either facultative resprouters and/or facultative seeders. Members of the Cistaceae family are only obligate seed regenerators. 
Table 16.2. Regeneration mode in some typical mediterranean plant taxa

\begin{tabular}{|c|c|c|c|c|}
\hline Taxa & Growth form & Life form & Sprouting & Seeding \\
\hline Pinus halepensis & Tree & $\mathrm{Ph}$ & & \\
\hline Pinus brutia & Tree & $\mathrm{Ph}$ & & + \\
\hline Quercus coccifera & Tall Shrub & $\mathrm{Ph}$ & + & - \\
\hline Pistacia lentiscus & Tall Shrub & $\mathrm{Ph}$ & + & - \\
\hline Pistacia terebinthus & Tall Shrub & $\mathrm{Ph}$ & + & - \\
\hline Arbutus unedo & Tall Shrub & $\mathrm{Ph}$ & + & - \\
\hline Arbutus andrachne & Tall Shrub & $\mathrm{Ph}$ & + & \\
\hline Erica arborea & Tall Shrub & $\mathrm{Ph}$ & + & \\
\hline Erica manipuliflora & Tall Shrub & $\mathrm{Ph}$ & + & \\
\hline Olea europea & Tall Shrub & $\mathrm{Ph}$ & + & \\
\hline Phillyrea latifolia & Tall Shrub & $\mathrm{Ph}$ & + & \\
\hline Cistus creticus & Shrub & $\mathrm{Ph}$ & & \\
\hline Cistus salvifolius & Shrub & $\mathrm{Ph}$ & & \\
\hline Cistus monspeliensis & Shrub & $\mathrm{Ph}$ & & + \\
\hline Phlomis fruticosa & Shrub & $\mathrm{Ph}$ & + & + \\
\hline Euphorbia acanthothamnos & Shrub & $\mathrm{Ph}$ & + & + \\
\hline Thymelea tartonraira & Subshrub & $\mathrm{Ch}$ & + & + \\
\hline Hypericum empetrifolium & Subshrub & $\mathrm{Ch}$ & + & + \\
\hline Fumana thymifolia & Subshrub & $\mathrm{Ch}$ & - & + \\
\hline Teucrium polium & Subshrub & $\mathrm{Ch}$ & + & + \\
\hline Ballota acetabulosa & Subshrub & $\mathrm{Ch}$ & + & + \\
\hline Coridothymus capitatus & Subshrub & $\mathrm{Ch}$ & - & + \\
\hline Asparagus aphyllus & Subshrub & $\mathrm{Ch}$ & + & \\
\hline Phagnalon graecum & Subshrub & $\mathrm{Ch}$ & + & \\
\hline Vicia villosa & Herb & Th & - & \\
\hline Vicia tetrasperma & Herb & Th & & \\
\hline Lotus ornithopodioides & Herb & Th & & + \\
\hline Cynosurus echinatus & Herb & Th & & + \\
\hline Asphodelus aestivus & Herb & $\mathrm{Cr}$ & & $?$ \\
\hline Arisarum vulgare & Herb & $\mathrm{Cr}$ & + & $?$ \\
\hline Ophrys lutea & Herb & $\mathrm{Cr}$ & + & $?$ \\
\hline Brachyphodium ramosum & Herb & $\mathrm{H}$ & + & - \\
\hline Scorzonera crocifolia & Herb & $\mathrm{H}$ & + & $?$ \\
\hline
\end{tabular}

$P h=$ Phanerophytes.

$\mathrm{Ch}=$ Chamaephytes.

$T h=$ Therophytes.

$\mathrm{Cr}=$ Cryptophytes.

$H=$ Hemicryptophytes.

Hemicryptophytes show both adaptation traits, while cryptophytes (including geophytes) seem to regenerate preferably by resprouting. Most of the representatives of the herbaceous therophytes are annuals and recover from fire through seed germination. However, there is evidence that many perennial herbs are resprouters. An extensive and detailed survey of the 
regeneration strategies of the Mediterranean taxa of Greece is currently underway and is expected to give more accurate percentages.

Data from other Mediterranean countries of the world reveal that among about half or more of trees or shrubs in regional floras are resprouting species (Keeley 1977a; Kruger 1977; Gill and Groves 1981), although there are characteristic genera that tend to have more seeding species.

\subsection{Post-Fire Succession}

Plant succession after fire in Mediterranean communities consists largely of the regeneration and development through the respective life cycle of the species present before fire (Specht et al. 1958; Hanes 1971; Arianoutsou 1979; Kazanis and Arianoutsou 1996). It is a process of secondary autosuccession in which the burned stand, although initially appearing to be different from the pre-burned one, retains its floristic identity in time. The most obvious change is that of the composition and relative abundance of annual herbaceous plants, followed by that of herbaceous perennials (Kazanis and Arianoutsou 1996). An impressively rich flora of these two groups is recorded in all Mediterranean plant communities of Greece after fire, being promoted either by increased temperature regimes prevailing during and immediately after fire (such as the leguminous plants) or by other factors which are currently investigated (e.g. nitrogenous compounds, fluctuating temperatures, changes in the light quality). As succession proceeds and the canopy closes, herbaceous vegetation is either restricted to small openings, as in the case of phryganic ecosystems and to a lesser degree in coniferous forests, or remains dormant in the soil in the form of seeds waiting for the next fire to come (Arianoutsou 1979; Kazanis and Arianoutsou 1996). Similar results have been reported by Specht et al. (1958) for heath stands in Australia, Bond (1980) for fynbos stands in South Africa, Horton and Kraebel (1955) for chaparral, Espirito-Santo et al. (1993) for sclerophyllous formations in Portugal, Faraco et al. (1993) for pine woodlands and shrublands in Spain, Mazzoleni and Pizzolongo (1990), De Lillis and Testi (1990), Lucchesi and Giovannini (1993) for similar communities in Italy.

The qualitative information on plant life histories and field observations allows us to summarize some highlights of the pyric succession in the Mediterranean plant communities of Greece, which are shown in Table 16.3. Mature stands vary considerably in the relative contribution of seeders versus that of sprouters both between the different types of Mediterranean ecosystems in Greece and within these types in relation to their 
Table 16.3. Highlights of early post-fire succession in Mediterranean ecosystems in Greece

\begin{tabular}{|c|c|c|c|}
\hline & Phrygana & $\begin{array}{l}\text { Evergreen } \\
\text { sclerophyllous } \\
\text { shrublands }\end{array}$ & Pine forests \\
\hline $\begin{array}{l}\text { Annuals and } \\
\text { short-lived } \\
\text { ephemerals }\end{array}$ & Abundant & Abundant & Abundant \\
\hline Geophytes & Many & Many & Many \\
\hline $\begin{array}{l}\text { Herbaceous } \\
\text { perennials }\end{array}$ & $\begin{array}{l}\text { Many (mostly } \\
\text { grasses) }\end{array}$ & $\begin{array}{l}\text { Many (mostly } \\
\text { grasses) }\end{array}$ & $\begin{array}{l}\text { Many (mostly } \\
\text { grasses) }\end{array}$ \\
\hline $\begin{array}{l}\text { Regeneration } \\
\text { mode of } \\
\text { dominant } \\
\text { woody } \\
\text { species }\end{array}$ & Sprouting/seeding & Sprouting & $\begin{array}{l}\text { Overstorey: seeding } \\
\text { Understorey: } \\
\text { sprouting/seeding }\end{array}$ \\
\hline $\begin{array}{l}\text { Timing of plant } \\
\text { recruitment }\end{array}$ & $\begin{array}{l}\text { Immediately after fre } \\
\text { (in the lst rainy } \\
\text { season for the } \\
\text { seeding species) }\end{array}$ & $\begin{array}{l}\text { Immediately after } \\
\text { fire }\end{array}$ & $\begin{array}{l}\text { In the first post-fire } \\
\text { rainy season }\end{array}$ \\
\hline $\begin{array}{l}\text { Fire-stimulated } \\
\text { germination }\end{array}$ & Yes & Not in shrubs & Yes \\
\hline $\begin{array}{l}\text { Development of } \\
\text { canopy cover }\end{array}$ & $\begin{array}{l}100 \% \text { in less than } 10 \\
\text { years }\end{array}$ & $100 \%$ in $\sim 5$ years & $\begin{array}{l}100 \% \text { in more than } \\
10 \text { years }\end{array}$ \\
\hline Diversity trends & $\begin{array}{l}\text { - Initially increases } \\
\text { - Decreases with age }\end{array}$ & $\begin{array}{l}\text { - Initially increases } \\
\text { - Decreases with age }\end{array}$ & $\begin{array}{l}\text { - Initially increases } \\
\text { - Decreases with age }\end{array}$ \\
\hline
\end{tabular}

successional stage (Table 16.4). Woody seeding species forming soil seed banks exist in all stages of phrygana, in relatively high numbers. Among these species rockroses are the most prominent. Resprouting woody species also occur throughout the successional cycle of phrygana, such as Jerusalem sage and Greek spiny spurge. In the evergreen sclerophyllous shrublands though, only sprouting shrubs like kermes oak, lentisc, strawberry tree etc., occur throughout the fire cycle. In pine forests sprouting and seeding shrubs can be found in either stages, but in very different numbers and cover. In the early successional stages, resprouters are competing with young tiny pine seedlings and seedlings of the other taxa. As the canopy closes, the understorey taxa are diminished in number and relative cover. Herbaceous species are present in the early successional stages of all three vegetation types, but they become less and less abundant as succession proceeds. Sprouting herbaceous perennials occur mainly at the early stages in the evergreen sclerophyllous shrublands and pine forests (Table 16.4). 
Table 16.4. Plant groups of different regeneration modes at three distinctive post-fire successional stages of mediterranean ecosystems in Greece

\begin{tabular}{|c|c|c|c|c|c|c|c|c|c|}
\hline & \multicolumn{2}{|c|}{ Phrygana } & \multicolumn{4}{|c|}{$\begin{array}{l}\text { Evergreen sclerophyllous } \\
\text { shrublands }\end{array}$} & \multicolumn{3}{|c|}{ Pine forests } \\
\hline & Early & Middle & Late & Early & Middle & Late & Early & Middle & Late \\
\hline $\begin{array}{l}\text { Seeding trees/ } \\
\text { shrubs }\end{array}$ & $++^{2}$ & $+\cdots$ & $t^{\mathbf{a}}$ & - & - & - & + & + & + \\
\hline $\begin{array}{l}\text { - canopy seed } \\
\text { bank }\end{array}$ & - & - & - & - & & & & & \\
\hline $\begin{array}{l}\text { - soil seed } \\
\text { bank }\end{array}$ & + & + & + & - & & & & & \\
\hline Sprouting shrubs & + & + & + & + & & & & & \\
\hline \multicolumn{10}{|l|}{$\begin{array}{l}\text { Herbaceous } \\
\text { perennials }\end{array}$} \\
\hline - seeding & $?$ & $?$ & $?$ & $?$ & $?$ & $?$ & & $?$ & $?$ \\
\hline - sprouting & + & $<+$ & $<+$ & + & - & - & & $<+$ & $<+$ \\
\hline \multicolumn{10}{|l|}{ Annuals } \\
\hline - seeding & + & $<+$ & $<+$ & + & $<+$ & - & & & \\
\hline
\end{tabular}

Similar patterns are reported for the other mediterranean-climate regions of the world. In chaparral, stands may consist of resprouting Adenostoma fasciculatum (Hanes 1977), but pure stands of the seeder Ceanothus megacarpus have been also reported (Schlesinger and Gill 1978). In Australian heathlands, sprouters appear to predominate (Russell and Parsons 1978; Specht 1981).

Among the various attempts which have been made so far in order to explain this variation two are more worthy of mention. Keeley (1977b) hypothesized that the relative success of seeders depends on the availability of openings in the post-fire regenerating vegetation, since they can exploit these spots and they have greater possibility to establish themselves away from competition from the resprouters. Thinning of a stand of sprouters progressively occurs in a normal fire interval, while live and dead fuel also accumulates. Thus the seeders, being relatively long-living taxa, have the advantage of establishing in these openings, from the dormant seed bank that they have formed in the ground. This pattern is mostly realised in long fire intervals, while in the short ones the ratio of seeders versus resprouters is decreased. It is therefore expected that under a variable fire frequency both forms may coexist. On the other hand, sprouters pose a competitive 
pressure on the seeders during post-fire regeneration, which has to do with exploitation of available moisture. As emphasized by Specht (1981), the extent of the foliage of the sprouters is determined by the available moisture. Thus, the more humid the environment, the less gaps are available to seeders. Therefore, the relative prevalence of either regeneration mode is considered a consequence of the site productivity.

Site productivity is not independent from fire regime, however, since repeated fires may lead to great loss of nutrients; on the other hand, prolonged absence of fire might have an analogous result, as decomposition rates and subsequent nutrient release are slowed down. It is fire, therefore, that acts as the primary force inducing this or the other pattern, through several secondary factors.

Data from the South African fynbos agree rather with the latter argument. Fynbos stands, including those on moist sites, have a number of species of both reproductive types, though often dominated by seeding shrubs (Kruger 1979; Bond 1980). The balance between seeders and sprouters is attributed to both an increase and a decrease in fire frequency.

All these quite often contradictory hypotheses need more concrete explanations, which require a more detailed demographic approach that will reveal the mechanisms underlying these patterns and which will predict the relative recruitment and mortality of sprouters and seeders as defined by site history.

\subsection{Plant Demography}

Studies performed in California have revealed two patterns of community recruitment: one in coastal sage shrubs, where there is a continual seedling production resulting in mixed-aged stands (Westman 1981), while in the chaparral seeding species produce seedlings only the first two post-fire years (Horton and Kraebel 1955; Quick 1959). This temporal seedling recruitment is one of the potential causes for chaparral stand decline (Westman 1981). Production of new stems by the resprouting species has not drawn much attention.

Data inserted in Tables 16.2-16.4 show the physiological traits of the plants and the way they are expressed in post-fire succession. Since vegetative regeneration seems not to be affected by the stage of the succession, at least not as much as regeneration by seeds, I will deal mostly with the latter. Data from Arianoutsou and Margaris (1981a) show that seed germination in the field occurs after the first rains in most of the seeding woody species of the burned phryganic ecosystems (Fig. 16.4), during the first post-fire 


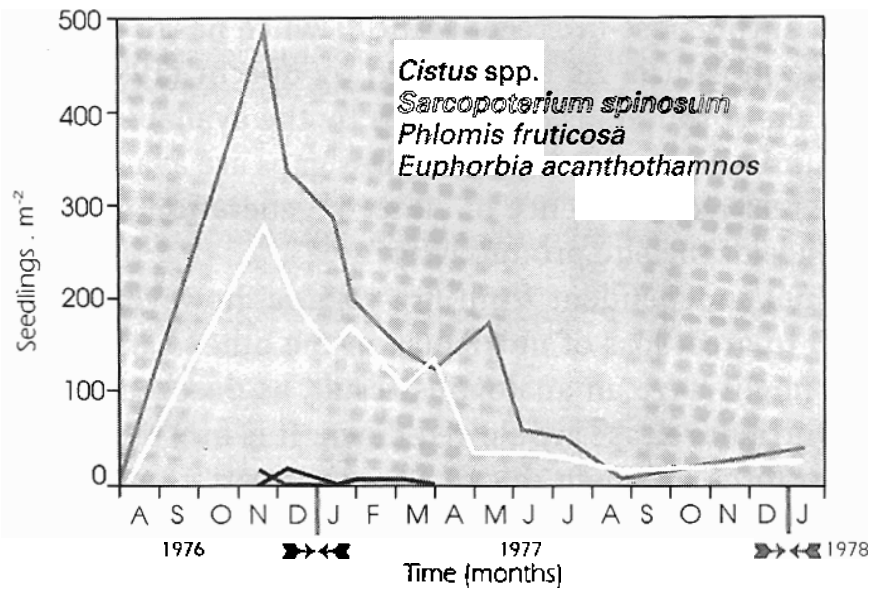

Fig. 16.4. Seedling density (indiv. $\mathrm{m}^{-2}$ ) during early post-fire succession in a phryganic ecosystem in Greece. (Arianoutsou and Margaris 19.81a)

year. Seed germination is not only enhanced by fire in many species but it results in significantly higher densities sometimes reaching 300 seedlings $\mathrm{m}^{-2}$, as in the case of Cistus species. Seed germination for the phryganic species tested so far reveals a mechanical rupture of the hard seedcoat for members of the Cistaceae (Arianoutsou and Margaris 1981b; Vuillemin and Bullard 1981; Thanos and Georghiou 1988; Trabaud and Oustric 1989; Roy and Sonie 1992) and for members of the Leguminosae (Doussi and Thanos 1993). Light quality has also been found as cueing seed germination for the phryganic species Sarcopoterium spinosum (Roy and Arianoutsou 1985).

From the few demographic studies in post-fire communities in the Mediterranean Basin a decrease in seedling density of woody taxa during the first post-fire year has been shown (Naveh 1974; Papanastasis 1977; Arianoutsou and Margaris 1981; Trabaud and Oustric 1989). No evidence of remarkable seed germination exists so far for these woody species during the second post-fire year, while there is very strong evidence that this does occur massively for several herbaceous ones, such as in the case of legumes (Fig. 16.5).

The juvenile phase for most of the woody species lasts only two years, that is they are at reproductive age when they are in the second year of their lives (pers. observ.). Data for seedling emergence of the dominant woody phryganic species in the field reveal that seed germination normally occurs even without fire (Figs. 16.6-16.10). It seems that fire plays an important role not in seed germination per se, since it is happening anyway, but in massive seed germination as a result of the creation of a micro- 


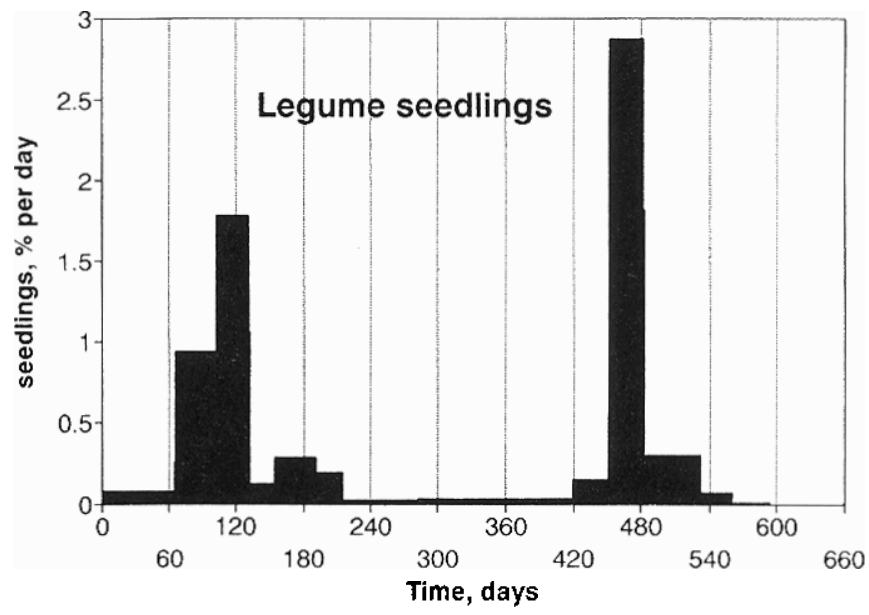

Fig. 16.5. Percentage increment of legume seedlings appearing on a burned Aleppo pine forest in Attica, Greece, during the first two post-fire years. (Papavassiliou and Arianoutsou, in prep)

environment making all of the conditions which are necessary for germina tion more available. This massive germination leads to the formation of a seedling reservoir from which community recruitment takes place much more easily. In other words, and as far as it concerns the dominant woody phryganic species, germination is regularly and continuously occurring, with a time lag of 1-2 years possibly, following the initial burst. The result of such a continuous seedling production is the existence of mixed-aged stands. The pyramid of age classes of $P$. fruticosa, E. acanthothamnos and Cistus spp. (Fig. 16.11) constructed with data drawn from a mature phryganic ecosystem, demonstrate this characteristic. Westman's data (1981) for coastal sage shrub formations are in full agreement with the above finding.

Roy and Sonie (1992) working with Cistus monspeliensis and Cistus albidus stands in southern France, have found that recruitment of both species occurred steadily during the five post-fire years, and then stopped. They claimed that seedling recruitment was related to canopy density. Data on similar perspectives are currently being gathered in Greece by our group.

It seems that the herbaceous taxa of these ecosystems generally follow the above pattern, being different in that they reach their reproductive maturity in the first post-fire year (Papavassiliou et al. 1994; Kazanis and Arianoutsou, unpubl. data).

Since almost all plants of the woody component in the evergreen sclerophyllous formations are resprouters we expect to have a mono- 

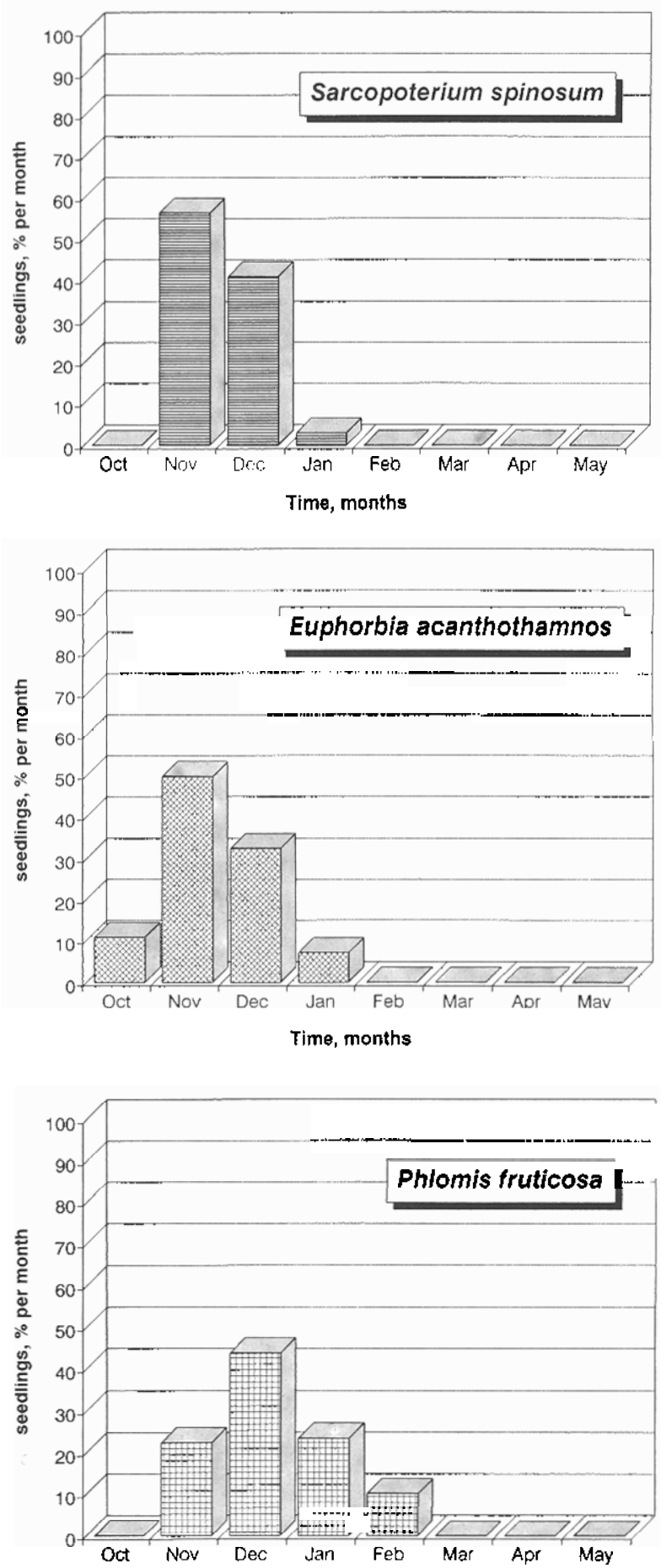

Fig. 16.6. Percentage increment of Sarcopoterium spinosum seedlings appearing in a mature phryganic ecosystem of Attica, Greece. (Data adapted from Argyris 1977)

Fig. 16.7. Percentage increment of Euphorbia acanthothamnos seedlings appearing in a mature phryganic ecosystem of Attica, Greece. (Data adapted from Argyris 1977)

Fig. I6.8. Percentage increment of Phlomis fruticosa seedlings appearing in a mature phryganic ecosystem of Attica, Greece. (Data adapted from Argyris 1977) 

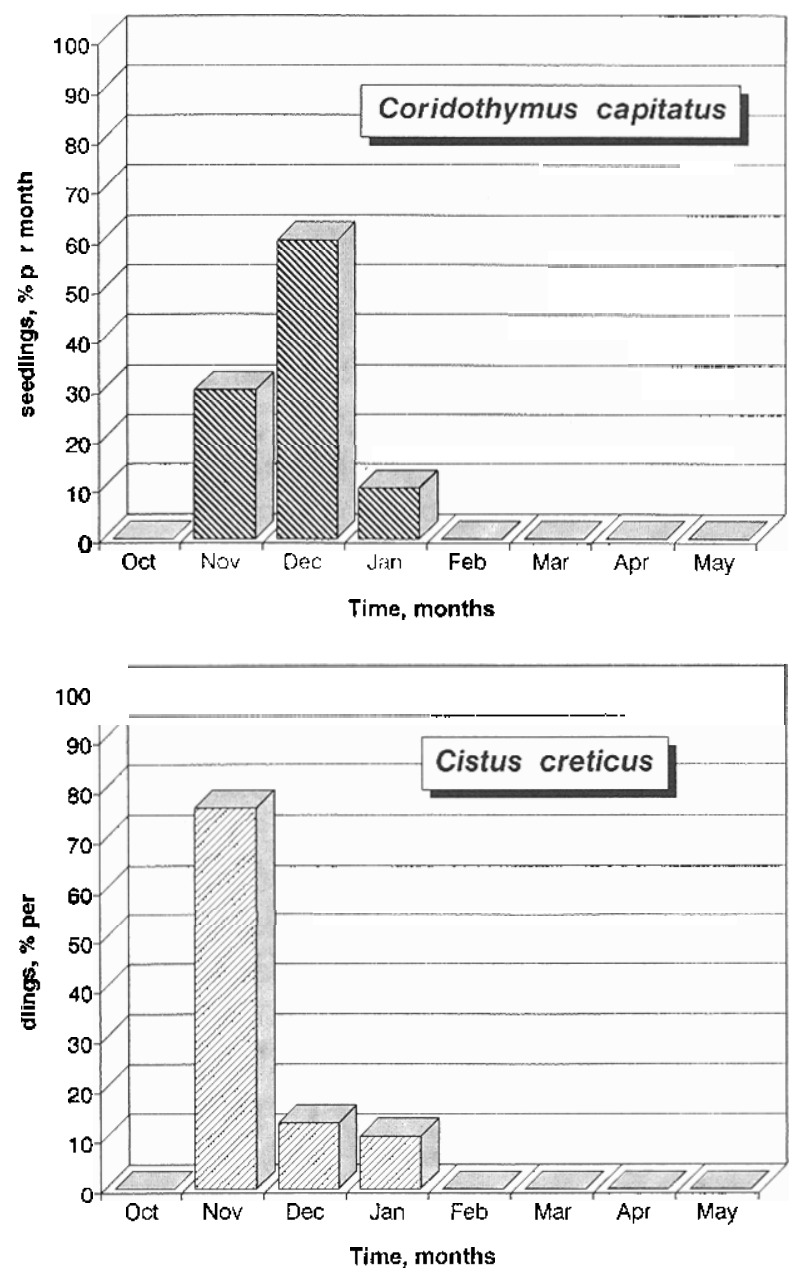

\section{Cistus spp.}
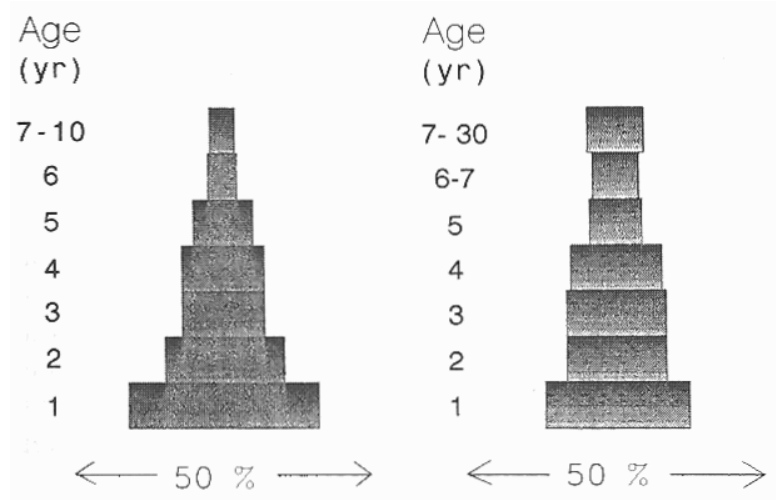

Fig. 16.9. Percentage increment of Coridothymus capitatus seedlings appearing in a mature phryganic ecosystem of Attica, Greece. (Data adapted from Argyris 1977)

Fig. 16.10. Percentage increment of Cistus creticus seedlings appearing in a mature phryganic ecosystem of Attica, Greece. (Data adapted from Argyris 1977)

\section{Phlomis fruticosa}

Age (yr)

$21-53$
$16-20$
$11-15$
$6-10$
$3-5$
2
1
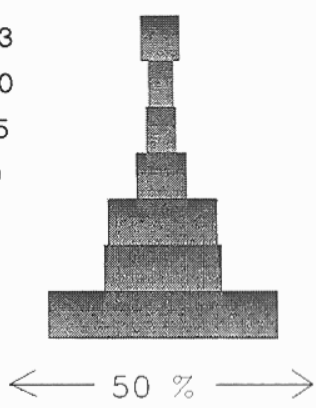

Fig. 16.11. Age structure of Cistus spp., Euphorbia acanthothamnos and Phlomis fruticosa populations in a mature phryganic ecosystem in Attica, Greece. (Arianoutsou and Margaris 19R21 
layered single-aged community, at least as far as concerns the aboveground plant parts. Although there is some information on shoot growth in these plants (Arianoutsou and Mardiris 1985; Perreira et al. 1985), almost nothing is available on shoot recruitment versus age - and this has to be done.

The situation in the pine forests is more complicated. Pine seeds germinate in a wave during the first post-fire year (Fig. 16.12) and almost no new seedlings are observed during the second post-fire year (Daskalakou 1996; Kazanis and Arianoutsou, unpubl. data). Pines reach their reproductive maturity after their sixth year (C.A. Thanos, pers. comm.) and have a considerably long life span, longer than 50 years. Germination in unburned pine forest is rather scarce and it usually occurs in gaps. According to Skordilis (1992), germination of pine seeds is light-controlled. Fire causes a massive seed release from the cones, the opening of which is induced by high temperatures developing during fres. The increased seed germination thus may be attributed to the more favourable light conditions (an ameliorated open environment).

There are not many detailed diachronic demographic studies for these pine species. Daskalakou (1996) has shown that seedling density of Aleppo pine is decreased drastically during the first post-fire year, reaching a number of 2.5 seedlings $\mathrm{m}^{-2}$ and further decreasing to 1.5 seedlings $\mathrm{m}^{-2}$ at the end of the second post-fire year. Similar results have been found in a post-fire chronosequence of Aleppo pine forest by Kazanis and Arianoutsou (unpubl. data). In contrast, Trabaud (1988) reported that mortality of Aleppo pine seedlings was generally low over a five year study. High mortality was also observed during the first post-fire year for East Mediterranean pine (Thanos et al 1989; Thanos and Marcou 1991, 1993; Spanos 1992, 1994).

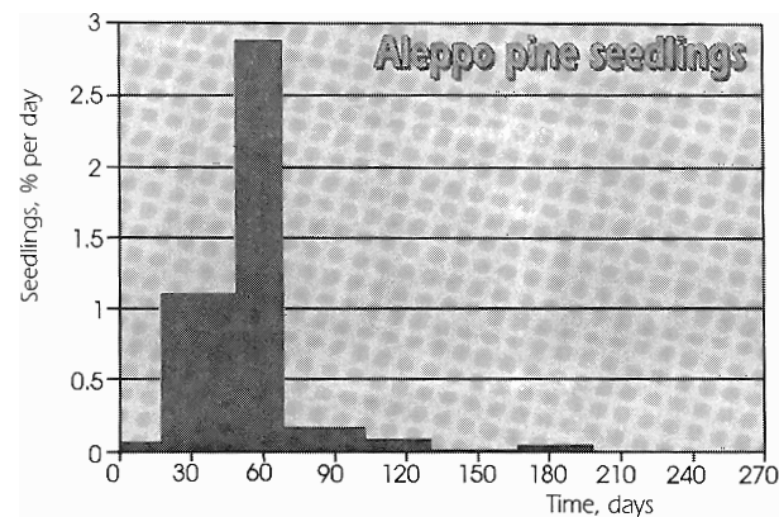

Fig. 16.12, Increment of Aleppo pine seedlings appearing in a burned forest of Attica during the first post-fire year. (Adapted from Daskalakou and Thanos 1997) 
All evergreen sclerophyllous species of the understorey regenerate vegetatively, actively posing an interspecific competition upon the young pine seedlings. Apart from these, the few representatives of seasonal dimorphic phrygana are mainly species of the Cistaceae, reestablishing mainly by seeds. Herbaceous annuals also germinate, while most perennial herbs resprout.

Gradually, as the canopy of the forest closes, the understorey taxa are restricted but they become more abundant again at the more mature stages, when the tree floor starts to thin out due to senescence (in the absence of fire) (Kazanis and Arianoutsou 1996).

\subsection{Seed Bank Dynamics}

Westman (1981) in his work with coastal sage shrubs claimed that a large proportion of the colonising flora, at least the herbaceous species, arrive by immigration from the adjacent unburned stands. This is unlikely to happen for many reasons, mainly because of the distances involved, the weakness of wind dispersal (Harper 1977; Cook 1980) and the rapid appearance of the herbs in the burned sites (Keeley 1980; Keeley et al. 1981). It is likely that the fire annuals of the chaparral behave like fugitive species, but since any single chaparral site is inevitably subjected to fire there is little selection towards long-range dispersal. In South African fynbos and in Australian heathlands the dominant shrubs are adapted to a short-range dispersal rather than to long-range modes (Williams 1972; Bond 1980; Berg 1981). Evidence from our studies in Greece confirms the latter theory, although some species may have evolved long-range dispersal through zoochory, as for example some legumes whose dispersal units "stick" to animals which graze the soft young post-fire growth, or seeds of the fleshy fruits of some evergreen sclerophyllous plants dispersed by birds.

Formation of soil seed banks is an alternative solution for those plants having short distance dispersal mechanisms (Fenner 1987). It seems that soil seed banks are the norm for the phryganic species which are obligate seed regenerators, as the Cistaceae, while canopy seed banks are the norm for the other obligate seed regenerators of the Mediterranean plant communities of Greece, the pines (Table 16.4). Not much research has been done so far for either of these, with some exception for Pinus halepensis (Daskalakou 1996), for some Cistaceae (Skourou and Arianoutsou, unpubl. data) and for pioneer annual legumes (Papavassiliou et al. 1994).

Searching the literature on seed bank dynamics in Mediterraneanclimate plant communities revealed only a few studies (Troumbis and 
Trabaud 1987; Zammit and Zedler 1988; Parker and Kelly 1989; Pierce and Cowling 1991). The topic of the timing of the formation of these reservoirs remains an open field for most of the Mediterranean communities.

\subsection{Life Span and Fecundity of Seeding Plants}

Among the woody species which are obligate seed regenerators, members of the Cistaceae have a relatively short life span of about 15 years (Fig. 16.11), while pines have a long life cycle. None of the facultative seed regenerators of the phryganic species examined so far appear to be short-lived. On the contrary there were individuals of Euphorbia acanthothamnos more than 50 years old (Fig. 16.11).

Australian and fynbos heathland seeding species have relatively short life spans (Kruger 1983), while life span of Californian Ceanothus species many of which are typical seeding taxa - is reported to be relatively limited, although it can reach to $40-60$ years (Hanes 1977; Keeley 1975).

At this point, I think it is worthwhile discussing what is a short and what is a long life span, as well as the signficance of life span in relation to fire. If we were not referring to a fire prone environment, life span would probably have less importance. But in the Mediterranean climate it becomes crucial, especially if some plants rely upon recurrent fires for their recruitment and existence.

None of the Mediterranean plants of Greece seem to be strictly dependent upon fire for its recruitment. Even post-fire obligate seed regenerators such as rockroses and pines do germinate without fire, as Fig. 16.9 shows for the former and repeated observations in forest gaps and sideways have shown for the latter. It is beyond any doubt that massive population recruitment for these species is greatly facilitated by fire, but would they die if it does not happen? I believe that they would not. On the contrary, the problem lies to those long-lived species which have extended juvenile periods, such as pines, which are expected to become extinct not in the absence of fire but in very frequent fires at intervals shorter than the minimum time which is necessary for full regeneration maturity.

This brings us to the next very important issue of plant demography, which is the fecundity schedule. Very few data are available for either Mediterranean-type ecosystems. Specht et al. (1958) showed accelerating fruit production from about nine years to between 20 and 25 , with some decline afterwards. Bond (1980), however, did not find a similar trend in fynbos. Keeley and Keeley (1977) reported that reproductive vigour is maintained with advancing age in the dominant seeding chaparral species. 
For seeders in Greek Mediterranean formations, a broad survey has recently started within the frame of the two research projects mentioned earlier, namely MODMED and PROMETHEUS which are expected to produce such data.

Finally, although there is much evidence that initially high post-fire density of all seeding species gradually becomes lower (see above-cited references), almost no data are available on density-dependent or independent mortality of seedlings.

\subsection{Conclusions}

It is evident from the above that there is a considerable gap of knowledge in vegetation dynamics, species replacement patterns and demography in the fire prone Mediterranean communities of Greece and of the Mediterranean Basin. The need to fill such a gap does not only originate from a merely scientific interest. Rational landscape management must be strongly dependent on its carrying capacity, which is defined by community structure, diversity and plant demographic features, as they are all influenced by the seasonal and geographical variation of the abiotic environment. Increased attention has recently been given to the issues of degradation and desertification threats, especially under a changing environment, both in socio-economic terms as well as climatically. None of the proposed models prepared to describe these processes, regardless of how sophisticated they might be, will be reliable unless they accurately represent the complexity of the Mediterranean landscapes and the ecosystems they support. And this can only be achieved through the evaluation of real data. The challenge is there and I hope that we will meet it.

Acknowledgements. The author expresses her thanks to the European Union for funding under the projects MODMED (EV-CT94-0489, ENV4-CT95-0139) and PROMETHEUS (EV-CT94-0482).

\section{References}

Argyris J (1977) The ecology of seeds of some phryganic species. PhD Thesis, University of Athens

Arianoutsou M (1979) Biological activity after fire in a phryganic ecosystem. PhD Thesis, University of Thessaloniki

Arianoutsou M (1984) Post-fire successional recovery of a phryganic (East Mediterranean) 
Arianoutsou M, Margaris NS (1981a) Producers and the fire cycle in a phryganic ecosystem. In: Margaris NS, Mooney HA (eds) Components of productivity of mediterraneanclimate regions - basic and applied aspects. Dr W. Junk, The Hague, pp 181-190

Arianoutsou M, Margaris NS (1981b) Early stages of regeneration after fire in a phryganic ecosystem (East Mediterranean). I. Regeneration by seed germination. Ecol Medit 7:1 19128

Arianoutsou M, Margaris NS (1982) Phryganic (East Mediterranean) ecosystems and fire. Ecol Medit 8:473-480

Arianuutsou M, Mardiris Th (1985) Obsernatiuns on the phellougy of the dominant plants

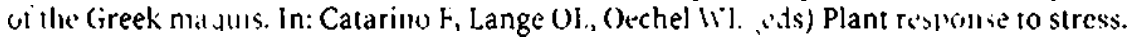
Functional analysis in mediterranean ecosystems. Springer, Berlin Heidelberg New York, pp 515-519

Barry J (1960) Contribution a l' étude de la vegetation de la region de Nimes. III. Les stades preforestiers. Ann Biol 36:311-540

Berg RY (1981) The role of ants in seed dispersal in Australian lowland heathland In: Specht RL (ed) Ecosystems of the world, vol 9B. Heathlands and related shrublands. Elsevier, Amsterdam, pp 51-59

Bond W (1980) Fire and senescent fynbos in Swartberg, southen Cape. S Afr For J 114:6871

Christensen NL, Muller $\mathrm{CH}$ (1975) Effects of fire on factors controlling plant growth in Adenostoma chaparral. Ecol Monogr 45:29-55

Cook R (1980) The biology of seeds in the soil In: Solbrig OT (ed) Demography and evolution in plant populations. Blackwell, Oxford, pp 51-59

Daskalakou E (1996) Ecophysiology of post-fire regeneration of Aleppo pine. PhD Thesis, University of Athens

DeLillis M, Testi A (1990) Post-fire dynamics in a disturbed mediterranean community in central Italy. In: Goldamner JG, Jenkins MJ (eds). Fire in ecosystem dynamics. Mediterranean and northern perspertives. SPB A:ademic, "The Hague, pp 53-62

Dousi M, Thanos $(\mathrm{M})(1993$, The ecophysiology of fire-induce. germination in hard-sceded plants. In: Come D, Corbineau F (eds) Basic and applied aspects of seed biology. ASFIS, Paris, pp 455-460

Dugrand R (1964) La garrigue montpellieraine. PVF, Paris.

Daskalakou E, Thanos CA (1997) Postfire establishment and survival of Aleppo pine seedlings. In: Balabanis P, Eftichidis G, Fantechi R (eds) Proc European School of Climatology and Natural Hazards Course, Porto Carras, Halkidiki, Greece. European Commission, pp 357-369

Espirito Santo MD, Rego F, Costa JC (1993) Vegetation dynamics in the Serra dos Candeeiros (central Portugal).In: Trabaud $L$, Prodon $R$ (eds) Fire in Mediterranean ecosystems. Ecosystem Research Report no 5, Commission of the European Communities, Brussels, pp 29-46

Faraco AM, Fernandez F, Moreno IM (1993) Post-fire vegetation dynamics of pine woodlands and shrublands in the Sierra de Gredos. In: Trabaud L, Prodon $\mathbf{R}$ (eds) Fire in Mediterranean ecosystems. Ecosystem Research Report no 5. Commission of the European Communities, Brussels, pp 101-112

Fenner $M$ (1987) Seed characteristics in relation to succession. In: Gray AJ, Crawley MJ, Edwards PJ (eds) Colonisation, succession and stability. Blackwell, Oxford, pp 103-114

Gill GM, Groves RH (1981) Fire regimes in heathlands and their plant ecological effects. In: Specht RI. (ed). Ecosystems of the world, vol 9B. Heathlands and related shrublands. Elsevier, Amsterdam, pp 61-84

Hanes TL (1971) Succession after fire in the chaparral of southern California. Ecol Monogr 41:27-52 
Hanes TL (1977) Chaparral. In: Barbour MG, Major J (eds). Terrestrial vegetation of California. Wiley, New York, pp 417-469

Harper JL (1977) Population biology of plants, Academic Press, London.

Higgs EJ, Vita-Finci C, Harris DR, Fagg AE (1967) The climate, environment and industries of Stone Age, Part III. Proc Prehist Soc 33:1-29

Horton JS, Kraebel CJ (1955) Development of vegetation after fire in the chamise chaparral of Southern California. Ecology 36:244-262

Kailidis D (1992) Forest fires in Greece. In: Ministry of Agriculture, Secretariat General for Forests and Natural Environment (tech coord). Proc Int Seminar on Forest Fire prevention, land use and people, Athens, Greece, pp 27-40

Kazanis D, Arianoutsou M (1994) Vegetation structure in a post-fire successional gradient of Pinus halepensis forests. In: Viegas DX (ed) Proc 2nd Int Conf on Forest Fire Research. Portugal, pp 979-993

Kazanis D, Arianoutsou M (1996) Vegetation composition in a post-fire successional gradient of Pinus halepensis forests in Attica, Greece, Int J Wildland Fïre, 6:83-91

Keeley JE (1975) Longevity of non-resprouting Ceanothus. Am Midl Nat 93:504-507

Keeley JE (1977a) Fire-dependent reproductive strategies in Arctostaphylos and Ceanothus. In: Mooney HA, Conrad CE (eds). Proc Symp on the Environmental consequences of fire and fuel management in mediterranean ecosystems, Palo Alto, California. USDA Forest Service Gen Tech Rep WO-3, pp 391-396

Keeley JE (1977b) Seed production, seed populations in the soil and seedling production after fire for two congeneric parts of sprouting and non-sprouting chaparral shrubs. Ecology 58:820-829

Keeley JE, Keeley S (1977) Energy allocation patterns of sprouting and a non-sprouting species of Arctostaphylos in the California chaparral. Am Midl Nat 98:1-10

Keeley JE, Zedler PH (1978) Reproduction of chaparral scrubs after fire: a comparison of sprouting and seeding strategies. Am Midl Nat 99:142-161

Keeley S, Keeley JE Hutchinson SM, Johnson AW (1981) Postfire succession of the herbaceous flora in Southern California. Ecology 62:524-530

Keeley JE, Nitzberg ME (1984) The role of charred wood in the germination of the chaparral herbs Emmenanthe penduliflora and Eriphyllum confertiflorum. Madroño 31:208-218

Keeley JE, Keeley S (1989) Allelopathy and the fire-induced herb cycle. In: Keeley JE (ed). The California chaparral. Paradigms re-examined. Natural History Museum of Los Angeles County, Los Angeles, pp 65-72

Kruger FJ (1977) Ecology of Cape Fynbos in relation to fire. Proc Symp on the Environmental consequences of fire and fuel management in mediterranean ecosystems, Palo Alto, California. USDA Forest Service Gen Tech Rep WO-3, pp 65-72

Kruger FJ (1979) Fire. In: Day I, Siegfried NR, Jarman ML (eds) Fynbos ecology: a preliminary synthesis. S Afr Nat Sci Prog Rep no 40, CSIR, Pretoria, pp 43-57

Kruger FJ (1983) Plant community diversity and dynamics in relation to fire. In: Kruger FJ, Mitchell DT, Jarvis JUM (eds) Mediterranean-type ecosystems: the role of nutrients. Springer, Berlin Heidelberg New York, pp 446-472

Liacos LG (1973) Present studies and history of burning in Greece. In: Proc 13th Annu Tall Timbers fire ecological conference, no 13, Tallahassee, Florida, pp 65-96

LeHouerou HN (1973) Fire and vegetation in the Mediterranean basin. In: Proc 13th Annu Tall Timbers fire ecological conference, no 13, Tallahassee, Florida, pp 237-277

Lucchesi S, Giovannini G (1993) Plant community dynamics following a fire: a case study in Toscany. In: Trabaud L, Prodon R (eds) Fire in Mediterranean ecosystems. Ecosystem Research Report no 5, Commission of the European Communities, Brussels, pp 47-54 Mazzoleni S, Pizzolongo P (1990) Post-fire regeneration patterns of Mediterranean shrubs

in the Campania region, southern Italy. In: Goldamner JG, Jenkins MJ (eds). Fire in 
ecosystem dynamics: Mediterranean and northern perspectives. SPB Academic, The Hague, pp 43-52

Mariolopoulos I, Karapiperis L (1955) Rainfall in Greece. Ministry for the Coordination

Mavromatis G (1978) Vegetation map of Greece. Institute of Forest Research. Athens, Greece

Mooney HA, Conrad CE (tech coord) (1977) Proc Symp on the Environmental consequences of fire and fue, mallagement in medits rrancar ecosystems, Palo Alto, Cialiturmia, USDA liorest service, Washimgton DC, Gousal I xh Rep WO 3

Naveh Z (1974) Effects of fre in the Mediterranean region. In: Kozlowski TT, Ahlgren CE (eds). Fire and ecosystems. Academic Press, New York, pp 410-434

Naveh Z (1975) Evolutionary significance of fire in the Mediterranean region. Vegetatio 29:199-208

Ne'eman $G$, Lahav $H$, Izhaki I (1993) The resilience of vegetation to fire in an eastMediterranean pine forest on Mount Carmel, Israel: the effect of post-fire management. In: Trabaud L, Prodon R (eds) Fire in Mediterranean ecosystems. Ecosystem Research Report no 5, Commission of the European Communities, Brussels, pp $127-141$

Papanastasis VP (1977) Fire ecology and management of phrygana communities in Greece. In: Mooney HA, Conrad CE (tech coord). Proc Symp on the Environmental consequences of fire and fuel management in mediterranean ecosystems, Palo Alto, Califormia, USDA Forest Service, Washington DC, General Tech Rep WO-3, pp 476-482

Papavassiliou S, Arianoutsou M, Thanos CA (1994) Aspects of the reproductive biology of fire following species of Leguminosae in a Pinus halepensis Mill. Forest. In: Viegas DX (ed) Proc $2^{\text {nd }}$ Int Conf on Forest Fire Research, Portugal, suppl.

Parker VT, Kelly VP (1989) Seed banks in California chapartal and other Mediterranean climate shrublands. In: Leck MA, Parker VT, Simpson RL (eds) Ecology of seed banks. Academic Press, San Diego, pp 231-255

Perreira JS, Beyschlag G, Lange OT, Beyschlag W, Tenhunen JD (1985) Comparative phenology of four mediterranean shrub species growing in Portugal. In: Catarino F, Lange OL, Oechel WC (eds). Plant response to stress. Functional analysis in mediterranean ecosystems. Springer, Berlin Heidelberg New York, pp 503-514

Pierce SM, Cowling RM (1991) Dynamics of soil-stored seed banks of six shrubs in fireprone dune fynbos. J Ecol 79:731-747

Purdie RW (1977) Early stages of regeneration after burning in dry sclerophyllous vegetation. I. Regeneration of the understory by vegetative means. II. Regeneration by seed germination. Aust J Bot 25:21-34, 35-46

Quick CR (1959) Ceanothus seeds and seedlings on burns. Madroño 3:135-140

Roy J, Arianoutsou M (1985) Light quality as the environmental trigger for the germination of the fire-promoted species Sarcopoterium spinosum L. Flora 177:345-349

Roy I, Sonnie L (1992) Germination and population dynamics of Cisfus species in relation to fire. J Appl Ecol 29:647-655

Rundel PW (1981) Fire as an ecological factor. In: Lange OL, Nobel PS, Osmond CB, Ziegler $\mathrm{H}$ (eds) Encyclopedia of plant physiology. vol 12A. Physiological plant ecology. Springer, Berlin Heidelberg New York, pp 501-538

Russell RP, Parsons RF (1978) The effect of time since fire on heath floristics at Wilson's Promontory, southern Australia. Aust J Bot 26:53-61

Schlesinger WH, Gill DS (1978) Demographic studies of the chaparral shrub, Ceanothus megacarpus, in the Santa Ynez Mountains, California. Ecology 59:1256-1263

Skordilis A (1992) Seed germination and seedling development in Pinus halepensis and $P$. brutia: physiological and ecological approach. PhD Thesis, University of Athens

Spanos YA (1992) Structure analysis and regeneration of Brutia pine in Thasos island. Ph.D. Thesis, University of Thessaloniki 
Spanos YA (1994) Natural regeneration of Pinus brutia in northwest areas of Thasos island, burned in 1989. Geot Epistim Themata (Greece) 4:33-39

Specht RL (1981) Responses to fires of heathlands and related shrublands. In: Gill AM, Groves RH, Noble IR (eds) Fire and the Australian biota. Australian Academy of Sciences, Canberra, pp 395-414

Specht RL, Rayson P, Jackman ME (1958) Dark island heath (Ninety-Mile Plain, South Australia). VI. Pyric succession: changes in composition, coverage, dry weight and mineral nutrient status. Aust J Bot 6:193-202

Thanos CA, Georghiou K (1988) Ecophysiology of fire-stimulated seed germination in Cistus incanus \$sp. creticus (L.) Heywood and C. salvifolius L. Plant Cell Environ 11:841849

Thanos CA, Marcou S (1991) Post-fire regeneration in Pinus brutia forest ecosystems of Samos island (Greece): 6 years after. Acta Oecol (Oecol Plant) 12:633-642

Thanos CA, Marcou 5 (1993) Natural regeneration of Pinus brutia forests of Samos island. Key events during the first 10 years of the postfire period. Int Symp on Pinus brutia. Ten, Turkey, pp 176-183

Thanos CA, Marcou S, Christodoulakis D, Yannitsaros A (1989) Early post-fire regeneration in Pinus brutia forest ecosystems of Samos island (Greece). Acta Oecol (Oecol Plant) 10:70-94

Trabaud L (1980) Influence du feu sur les semences enfouies dans les couches superficielles du sol d'une garrigue de Chene kermes. Naturalia monspeliensia. Ser Bot 39:1-12

Trabaud L (1988) Survie de jeunes plantules de pin d'Alep apparus apres incendie. Stud Oecol 5:151-170

Trabaud L, Oustric J (1989) Heat requirements for seed germination of three Cistus species in the garrigue of southern France. Flora 183:321-325

Troumbis A, Trabaud L (1987) Dynamique de la banque de graines de deux especes de Cistes dans le maquis grec. Acta Oecol (Oecol Plant) 8:167-179

Vuillemin J, Bullard C (1981) Ecophysiologie de la germination de Cistus albidus L. et Cistus monspeliensis L. Naturalia monspeliensia. Ser Bot 46:1-11

Westman WE (1981) Coastal sage scrub succession. In: Mooney HA, Conrad CE (tech coord). Proc Symp on the Environmental consequences of fire and fuel management in mediterranean ecosystems, Palo Alto, California, USDA Forest Service, Washington DC, General Tech Rep WO-3, pP 91-96

Williams IJM (1972) A revision of the genus Leucadendron (Proteaceae). Contrib Bolus Herb 3:1-425

Zammit CA, Zedler PH (1988) The influence of dormant shrubs, fire and time since fire on soil seed banks in mixed chaparral. Vegetatio 75:175-187 